Vietnamese scientists, while the overall findings are set in context by general overviews written by American, British and Swedish scientists. Their conclusions are that Vietnam's inland and mangrove forests not only suffered immediate and extensive damage as a result of the spraying, but that the effects persist. Only a replanting programme - already begun by the Vietnamese - on a massive scale will heal the scars of war. For this work to succeed time and international help will be required.

The effects of the various chemical agents on the health of the population is more difficult to judge. Vietnamese scientists believe that the herbicides caused an increase in the incidence of liver cancer and in the number of children born with handicaps. Regrettably it is too early to assess both claims; the evidence is still far from complete and much more information will need to be gathered to resolve the issue. Meanwhile the population of Vietnam has to live with uncertainty. It will be little consolation that the havoc visited upon their country has led to moves to prevent the same thing happening again elsewhere.

In 1977, outrage over the attempted manipulation of the environment of
Indochina went a stage further than mere condemnation, with the enactment of the Environmental Modification (ENMOD) Convention. The Convention was designed to prohibit acts of war intended to change the natural environment, but fell short of what was required. Environmental Warfare reviews the agreement and points out how the text of the 1977 drafting should be tightened to exclude totally any manipulation of the environment by armed forces (some is still permitted) and to outlaw research on methods of manipulation for hostile purposes.

In the heat of battle there will be no time, nor desire, to agree codes of conduct; such agreements need to hammered out in calmer times. A nuclear war, with the ensuing nuclear winter, may render some of these resolutions academic, but in the event of more conventional warfare we will be glad of them. These two publications will be invaluable for bringing that lesson home.

Alastair Hay is a Lecturer in the Department of Chemical Pathology at the University of Leeds. With Seán Murphy and Steven Rose, he is coauthor of No Fire, No Thunder: The Threat of Chemical and Biological Weapons (Pluto Press, 1984).

\section{Regulation damage}

\section{Anne H. Ehrlich}

Environmental Policy in the 1980s:

Reagan's New Agenda.

Edited by Norman J. Vig and Michael E.

Kraft.

Congressional Quarterly Inc., 1414 22nd Street NW, Washington DC 20037: 1984. Pp.377. Pbk \$12.95.

SINCE shortly after Ronald Reagan took office as President of the United States, environmentalists have protested that violence is being done to America's hardwon federal regulatory apparatus for environmental protection and resource management. The means, it is alleged, are administrative fiat and selective budgetslashing. Now a group of scholars with an impressive array of academic credentials has analysed the Reagan team's record in administering the government's resource and environmental programmes. They have produced a detailed indictment of that record, as resounding as anything so far issued by even the most militant of environmental organizations.

Some of the territory explored by Norman Vig, Michael Kraft and the 15 other contributors to this collection is familiar to the public. Most notably there have been the scandalous goings-on at the Environmental Protection Agency (EPA) - the reign and departure in disgrace of its administrator Anne Gorsuch-Burford, and the belated attempt to rescue the agency's remaining shreds of credibility by appointing William Ruckleshaus as its head in 1983 - not to mention the achievements of Reagan's remarkably insensitive (both socially and environmentally) first Secretary of the Interior, James G. Watt.

Meanwhile, however, other events of questionable legitimacy have occurred without attracting the limelight - the dismantling of the Department of Energy's information-gathering and research capabilities and its programmes to encourage conservation and development of alternative energy sources; the mutually contradictory policies of forest management in the Department of Agriculture; and the abdication of the nation's role of world leadership in environmental protection and global resource management. An example of the last, which did attract public attention but occurred too late for inclusion in this book, was the Reagan administration's ludicrous performance at the United Nations' World Population Conference last August in Mexico City.

Vig, Kraft and their co-authors scrutinize these and other actions, the effect (and, evidently, intent) of which has been to weaken, if not cripple, the environmental regulatory power of the federal government. The book also presents a history of environmental legislation and regulation at the federal level, a discussion of the misconstrued electoral "'mandate" for the sweeping changes that were effected, and an assessment of the long-term damage inflicted on the government's institutions by the Reagan regime in just three years.

The administration's attempts to revise

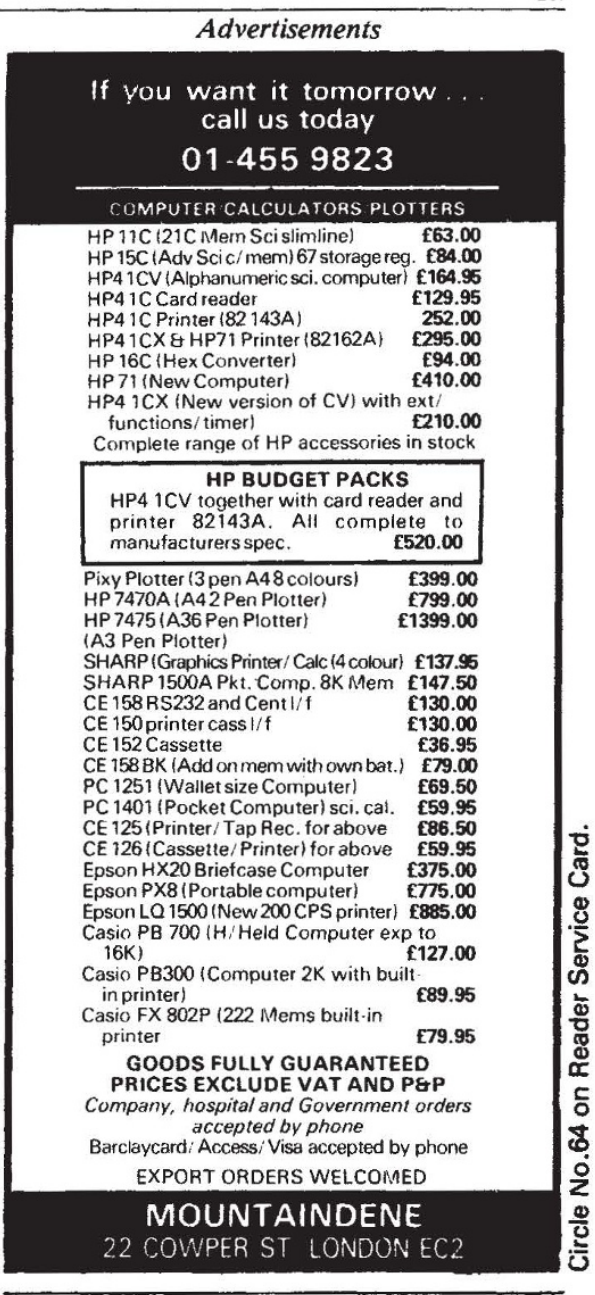

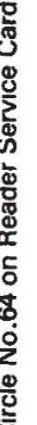

\section{ITE publications} METALS IN ANIMALS

\section{Editor D. Osborn}

ITE Symposium volume no. 12 covering many aspects from effects of metals on wildlife to advanced chemical techniques (NMR).

19840904282775 paper 77pp 44

£3.50

\section{BRITAIN'S RAILWAY VEGETATION}

Caroline Sargent

Habitat, vegetation forms and influences that have combined to produce them are described; decline and success of railway species; predictive model and conservation strategy.

19840904282767 paper 34pp A4

MOORLAND MANAGEMENT: a study of Exmoor

G.R. Miller, J. Miles \& O.W. Heal

Ecological management for agriculture, spor and conservation, with special reference to Exmoor.

19840904282781 paper 118pp A4 $£ 4.50$

Three of the recent publications from the Institute of Terrestrial Ecology. Full list of all publications available.

ITE, Administrative Headquarters, Monks Wood, Abbots Ripton, HUNTINGDON, Cambs. PE17 2LS. 
environmental laws, the conventional strategy by which presidents make policy changes, were largely rebuffed by Congress, which in turn had been subjected to increasing pressure from the public, both directly and through revitalized environmental groups. But Congress has little control over administrative decisions; while it could partially restore ravaged budgets, it could not force administrators to spend the money.

To a large extent, as the authors make clear, the administration's actions have been counterproductive to their intended ends. The fiasco at the EPA not only defeated the goal, once shared by regulated industries and environmentalists alike, of reforming the existing regulatory framework to make it more effective, efficient and fair; it backfired. By politicizing regulatory affairs, and either firing or alienating the EPA's professional staff, the EPA administration under Gorsuch set back the clock on much needed regulatory reassessment. Richard Andrews, author of the chapter on the EPA, comments:

The attempt to achieve radical policy change by means of ideological loyalist appointees untainted by experience thus stands as probably the single most reckless tactic, and clearest failure, in Reagan's policy strategy.

Similarly, the administration's efforts to weaken the Clean Air Act may have led to more, not less, rigidity in regulation and increased mistrust between regulators and the regulated.

The Reagan team's actions have also been self-contradictory. Complaining on one hand that insufficient information existed to justify certain programmes, it proceeded to kill research projects that could provide the necessary data. Describing the relinquishment of the Department of
Energy's responsibilities for datacollecting and analysis, Regina Axelrod drily observes: "No government in recent times has sought to beat its opponents by declaring war on information".

Professors Vig and Kraft have produced not only a stinging critique of Ronald Reagan's environmental policies, but a useful, general text on the making and implementing of environmental policy at the federal level in the United States. Its viewpoint is generally pro-environment, yet it is sympathetic to the needs of business and industry for reasonable, consistent and even-handed environmental regulations. The book unfortunately suffers from a certain amount of repetition and overlap, but that perhaps is an inevitable result of the difficulty in orchestrating the efforts of 17 authors.

Beyond its value as a text on environmental policies, the book provides an instructive case-history of an "administrative presidency" - a presidency that effects policy changes through administrative decisions. In this instance, the changes have been both unprecedentedly radical and lacking public consensus. Political scientists no doubt will find food for thought for years to come, not only in the lessons the Reagan presidency offers for eluding the complex checks and balances built into the government's structure and the degree of change that it successfully brought about despite them, but also in the failure of the American public to hold Ronald Reagan personally responsible for policies that it clearly does not support.

Anne H. Ehrlich is a Senior Research Associate in the Department of Biological Sciences, Stanford University.

\section{Boffin's progress}

\section{Robert Cockburn}

\section{Bernard Lovell: A Biography.}

By Dudley Saward.

Robert Hale, London: 1984. Pp.320.

f12.95.

BORN in Gloucestershire in 1913, Sir Bernard Lovell is a worthy successor to the bold buccaneers who thrived in the West Country during the reign of the first Elizabeth. He is a man of ruthless energy, an outstanding scientist, an engineer faute de mieux, but above all an inspired leader.

The author of this biography was a Group Captain on the staff of Bomber Command during the Second World War, collaborating closely with Lovell, and he has remained an intimate friend of the family ever since. So Saward is well qualified to write a definitive account of Lovell's life and works, though he sometimes tends to include facts from his own experience which are not particularly rele- unprepared for night bombing and its performance over Germany was lamentable. The introduction of $\mathrm{H}_{2} \mathrm{~S}$, first into the Pathfinders and then to the main bomber force, improved its efficiency by an order of magnitude. It was to this end that Lovell directed his redoubtable energies; he transgressed every rule in the book, scrounged endlessly, and by sheer bloody-mindedness cut through all the usual organizational restraints. It was a personal achievement of the highest order. As the end of the War came in sight, and the pressures on TRE eased, many of the leading figures collapsed after four years of unremitting toil. Lovell was no exception, although he recovered rapidly.

As soon as he arrived back at the University of Manchester in 1945, Lovell applied himself with characteristic determination to equipping the green-field site at Jodrell Bank with apparatus purloined from the Services, and to laying the foundations for his subsequent career as a radioastronomer. It was in 1950 that the idea for a huge steerable telescope caught his imagination, and the fruitful collaboration with H.C. Husband commenced Husband was the only engineer in the country prepared to design such a novel and advanced structure. Nowadays we are inured to the inevitable escalation of costs during the development of an advanced project. At that time the Department of Scientific and Industrial Research, the funding agency, was unused to such expensive investments, and throughout the seven years that it took to bring the telescope into operation there was continuous wrangling over finances. Used to the lavish wartime expenditure, Lovell found peacetime restraints irritating in the extreme; but loyally backed by Manchester University, and by P.M.S. Blackett and other far-sighted senior scientists, he forced the project through with the same drive that he had used with such effect during the War. There were undoubtedly frequent bouts of depression and frustration, but his resolve remained firm.

At the very last stage, when the equipment was on the verge of operation, public opinion swung in his favour when it was realized that the telescope was the only facility in the world capable of tracking the Sputniks. For the next three years Jodrell Bank was used by both the Americans and the Russians as a vital tracking station for their space probes. Lovell was by now an international figure, and was invited to the United States and USSR where he was received with the greatest courtesy and respect, and was able to arrange several collaborative projects.

In addition to all his research work Lovell found time to write a large number of books and give lectures, and for numerous public duties. As a member of the Science Research Council and chairman of the Astronomy Space and Radio Board, he became involved in wider issues of national policy. At one point, in 